\title{
State of Authority
}

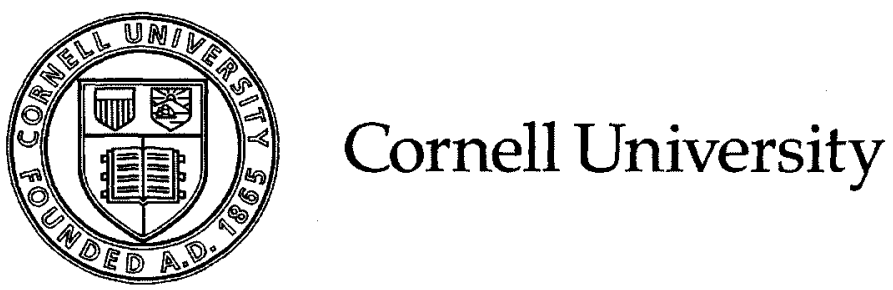


This page intentionally left blank 
Gerry van Klinken and Joshua Barker, editors

\section{State of Authority The State in Society in Indonesia}

Southeast Asia Program Publications

Southeast Asia Program

Cornell University

Ithaca, New York

2009 


\section{Editorial Board}

Benedict R. O'G. Anderson

Thak Chaloemtiarana

Tamara Loos

Keith Taylor

Andrew C. Willford

Cornell Southeast Asia Program Publications

640 Stewart Avenue, Ithaca, NY 14850-3857

Studies on Southeast Asia No. 50

(C) 2009 Cornell Southeast Asia Program

All rights reserved. Except for brief quotations in a review, no part of this book may be reproduced or utilized in any form or by any means, electronic or mechanical, including photocopying and recording, or by any information storage or retrieval system, without permission in writing from the Cornell Southeast Asia Program.

Printed in the United States of America

ISBN: hc 978-087727-780-4

ISBN: pb 978-087727-750-7

Cover Design: Kat Dalton

Cover Image: Photograph by Ian Wilson, reprinted with permission 